\title{
Gebelik sırasında tanısı koyulan primer hepatik siroz: olgu sunumu ve literatürün gözden geçirilmesi
}

\section{Primary liver cirrhosis diagnosed during pregnancy: a case report and literature review}

\author{
Abdullah GÖYMEN1, Yılmaz BILGiÇ², Yavuz ŞiMŞEK³a
}

1Sanko Üniversitesi Tıp fakültesi Kadın Hastalıkları ve Doğum AD, 2̇nönü Üniversitesi Tıp Fakültesi Gastroenteroloji AD, 3Özel YS Kadın Doğum Kliniği Kırıkkale - TÜRKiYE

\section{ÖZET}

Karaciğer sirozu olan kadınlarda fertilite olumsuz etkilenir ve nadiren gebelik elde edilebilir. Öte yandan karaciğer hastalıklarının tedavisindeki güncel gelişmelerin sonucu olarak, bu hastalarda yaşam beklentisi ve fertilite imkanı artmıştı. Böylelikle günümüzde sirozlu gebe kadınlarla daha fazla karşılaşılmaktadır. Günümüzde sirozlu gebelerin takibi ve yönetimi ile ilgili belirlenmiş standart yaklaşımlar bulunmamaktadır. Bu hastalarda obstetrik, perinatal, metabolik ve cerrahi riskler artmakta; sonuçta maternal ve fetal mortalite oranları yükselmektedir. Bu yazıda kliniğimizde altı haftalık gebelik saptanan ve viral etiyolojiye bağlı siroz tanısı koyulan bir hastanın takibi ve yönetimi sunularak konu literatür bilgileri eşliğinde tartışıldı.

Anahtar Kelimeler: Siroz, Hepatit B enfeksiyonu, gebelik, tedavi

\section{ABSTRACT}

Liver cirrhosis influences negatively fertility of women and pregnancies are rarely achieved. However, in these cases life expectancy and fertility chance have been increased due to the consequences of current achievements in the treatment of chronic liver diseases. Thus, currently, pregnant women with cirrhosis are more frequently encountered. Nowadays, standardized guidelines regarding to the follow-up and management of pregnant women with cirrhosis have not been established. Obstetrical, perinatal, metabolic and surgical risks of these cases are increased; in this manner maternal and fetal mortality rates are increased. In the current report, the management and follow-up of a pregnant woman at six weeks of gestation with the diagnosis of cirrhosis due to viral etiology were presented and the topic was discussed along with the literature review.

Key Words: Cirrhosis, Hepatitis B infection, pregnancy, treatment

\section{Giriş}

Yaygın fibrozis ve rejeneratif nodüllerle karakterize olan siroz, karaciğer parankim hastalıklarının son aşamasıdır. Reprodüktif çağdaki kadınlarda siroz prevalansı 0,45/1000 olarak bildirilmiştir [1]. Gebeliği komplike eden sirozun nadiren görülmesinin temel sebebi , sirozun reprodüktif dönemin bittiği yaşlarda gözükmesi ve siroza bağlı metabolik anormalliklerin anovulasyon ve infertiliteye neden olmasıdır [2]. Bu nedenle sirozun gebelikteki gerçek insidansı tam olarak bilinmemektedir. Toplumda genel olarak sirozun en sık nedeni kronik alkol kullanımı iken; gebelerde en sık altta yatan etiyolojik neden Hepatit B ve Hepatit C virus enfeksiyonlarına sekonder postenfeksiyoz sirozdur [1]. Bu hastalarda sarıllk, ödem, koagulopati, metabolik anormallikler, portal hipertansiyon ve splenomegali yaygın görülen klinik bulgulardır. Semptomatik sirozu olan kadınlar genellikle infertildir. Hepatosit hasarı sonucu östrojen metabolizmasının bozulması, kronik hiperöstrojenemiye ve anovulasyona neden olarak bu hastalarda 
fertiliteyi olumsuz etkiler [2]. Gebelik sırasında ise hepatik yetmezlik, varis kanamaları, hepatik ensefalopati, splenik ven rüptürü, spontan abortus, preterm doğum, fetal gelişme geriliği, maternal ve fetal ölüm gibi ciddi komplikasyonların riskleri artar [1,3]. Özellikle özofageal varis ve ciddi portal hipertansiyon eşlik eden olgularda prognozun daha kötü seyrettiği bildirilmektedir [3,4]. Bu nedenle sirozlu hastalarda gebelik takibi, komplikasyonların erken tanınması ve yönetimi önem arz etmektedir. Bu yazıda gebeliği sırasında siroz tanısı koyulan Hepatit B taşıyıcısı bir hastanın yönetimi sunularak konu literatür bilgileri eşliğinde tartışıldı.

\section{Olgu}

26 yaşında, G1 P0 olan hasta adet gecikmesi ve sol üst kadranda ağrı yakınmalarıyla polikliniğimize başvurdu. Hastanın kan basıncı 130/80 mmHg; nabzı 92 atım/dk ve vücut sıcaklığı $36.5{ }^{\circ} \mathrm{C}$ saptandı. Fizik muayenede herhangi bir anormal bulgu saptanmadı. Yapılan transvajinal ultrasonografide 6 haftalık tek, canlı intrauterin gebelik saptandı. Hastanın öyküsünde Hepatit B taşıyıcılığı mevcuttu. Hastanın batın ultrasonografisinde dalak boyutları artmış olarak $17 \times 10 \mathrm{~cm}$; splenik ven çapı 12 mm ölçüldü ve dalak hilusunda çok sayıda venöz kollateral yapı saptandı. Ek olarak hastada splenorenal şant saptandı. Kronik karaciğer parankim hastalığı ön tanısı ile hastaya özofagogastroduodenoskopi yapıldı ve özofagus 1/3 distalinde kolonlar halinde Grade 1 varisler saptandı. Hastanın hemogramında hemoglobin ve beyaz küre sayımı normal ancak trombosit sayısı 59×103/ ml saptandı (150-400x103). Periferik yaymada trombositopeni doğrulandı ve mevcut trombositopenin splenomegaliye bağlı geliştiği tespit edildi. Koagulasyon testlerinde protrombin zamanı 18,3 sn (11-14,5); INR 1,5 (0,8-1,2); aktive parsiyel tromboplastin zamanı 32,9 sn (26-40) olarak belirlendi. Biyokimyasal testlerden direk bilirübin 0,53 mg/dl $(0-0,5)$; total bilirübin 2,97 mg/dl (0,2-1,2) saptandı, diğer biyokimya değerlerinde anlamlı değişiklik yoktu .Serolojik testlerden $\mathrm{HbsAg}$, anti-Hbe, total anti-Hbc pozitif; anti-Hbs, delta antijeni ve antikoru negatif idi.

Mevcut bulgularla hasta Hepatit B enfeksiyonu sonucu kompanse siroz olarak kabul edildi. Gastroenteroloji konsültasyonu sonucunda karaciğer biyopsisi yapılmasına gerek görülmedi. Hasta ve eşine yapılan danışmanlıkta, gebeliği sırasında özofagus varis kanaması, dekompanse siroz gelişimi, preterm doğum, intrauterin gelişme geriliği, maternal ve fetal ölüm gibi potansiyel komplikasyonların gelişebileceği bilgisi verildi ve aydınlatımış onamı alındı. Aile bilgilendirme sonrasında gebeliği istemediğini bildirdi. Dilatasyon ve küretaj ile gebelik sonlandırıldı. Tahliye sonrası erken dönemde herhangi bir komplikasyon gelişmedi. Siroz nedeniyle hastaya günlük $245 \mathrm{mg}$ oral tenofovir disoproksil (Viread, Gilead Sciencis(C), Foster City, Canada) tedavisi başlanarak takibe alındı [4].

\section{Tartışma}

Sirozlu kadınlarda karaciğer parankimindeki hasarın şiddeti bu olgularda ortaya çıabilecek obstetrik ve perinatal komplikasyonların en önemli belirleyicisidir [4]. Bu hastalarda mortalite \%10-18 arasında bildirilmektedir ve en önemli ölüm nedenleri sırasıyla özofagus varis kanaması ve hepatik yetmezlik gelişimidir [5,6]. Cheng ve ark.'nın çeşitli etiyolojilere sekonder siroz gelişmiş 117 gebeyi içeren serilerinde hastaların \%44,4'ünde gebelik sırasında karaciğer fonksiyonlarında bozulma; \%21,3'ünde hematemez geliştiği bildirilmiştir [7]. Gebelik sırasında hem ilk defa özefagus varis gelişimi; hem de var olan özofagus varislerinden kanama riskleri artmaktadır. Bu artış gebelikte \%50 oranında yükselen intravasküler volüm ile ve büyüyen uterusun vena kava inferior'a basısı ile ilişkilidir [1]. Tan ve ark. varis kanamalarının \%62'sinin volüm artışının en belirgin olduğu 20-26. Haftalar arasında gerçekleştiğini bildirmiştir [6]. Sunduğumuz olgudaki gibi sirozlu ve özofagus varisli gebelerin takibinde özellikle 2. trimester kanamalarına karşı hazırlıklı olmak takipte son derece önemli yer tutmaktadır. Kanamaların tedavisinde endoskopik band ligasyonu en etkin ve en sık kullanılan yöntemdir. Akılda tutulması gereken bir diğer nokta portal vendeki staz ve gebeliğin prokoagulan etkileri nedeniyle bu olgularda bir diğer mortalite ile ilişkili tablo olan portal ven trombozu sıkı̆ı̆ının da artmış olmasıdır [3-6]. Sunduğumuz hastada bu bilgiler ışığında yapılan danışmanlık sonucunda hasta tıbbi tahliye yönünde görüş bildirdi. Bu nedenle sirozlu gebelerde ilk vizitte uygun danışmanlık ile hastanın doğru bilgilendirilmesi olumsuz sonuçlardan kaçınmak için en etkili önlem olabilir. Sirozlu gebelerde spontan abortus, preterm doğum, postpartum kanama ve perinatal ölüm riskleri anlamlı oranda artar $[1,3,6]$. MacDorman ve ark.'nın derlemesinde sirozlu anne bebeklerinde perinatal ölüm riski \%18 olarak bildirilmektedir ve en önemli ölüm nedeni prematür doğumlardır [8].

Siroz tanısı için sunduğumuz olguda klinik, laboratuvar ve ultrasonografik bulgular yeterli kabul edilmiştir. Her ne kadar siroz tanısında karaciğer biyopsisi altın standart olsa da, günümüzde mevcut bulgular siroz tanısını desteklediğinde biyopsi yapılmayabileceği bildirilmektedir (9). Bu olgularda ayırıcı tanıda alkolik siroz, Hepatit C enfeksiyonu, Wilson Hastalığı, parenteral nutrisyon, abetalipoproteinemi, Reye Sendromu ve akut gelişen olgularda gebeliğin akut yağlı karaciğeri akılda tutulmalıdır $[3,4]$.

Sonuç olarak, kronik karaciğer hastalıklarının tedavisindeki gelişmeler sayesinde günümüzde sirozlu gebe ile karşılaşma intimali artmaktadır. Viral etiyolojiye bağı sirozlu kadınların takibi ve yönetimi ile ilgili literatür bilgilerimiz sınırlıdır ancak bu hastalarda metabolik, obstetrik ve perinatal morbidite ve mortalite riskinin anlamlı olarak arttığı bilinmelidir. Komplikasyonlara zamanında müdahale edebilmek için sirozlu gebelerin takibinin gastroenteroloji, genel cerrahi, perinatoloji ve pediatri uzmanlarının katılı̆̆ı multidisipliner bir ekiple yapılması yaşamsal önem taşımaktadır.

\section{Kaynaklar}

1. Günşar F. Gebelik ve Portal Hipertansiyon. Turkiye Klinikleri J Gastroenterohepatol-Special Topics 2008;1:85-8.

2. Douglas NC, Shah M, Sauer MV.Fertility and reproductive disorders in female solid organ transplant recipients. Semin Perinatol 2007;31:332-8.

3. Yazgan Y, Öncü K. Karaciğer Sirozu ve Gebelik. Güncel Gastroenteroloji. 2012;1644-9.

4. Tiribelli C, Rigato I: Liver cirrhosis and pregnancy. Ann Hepatol 2006, 5:201.

5. Garcia-Tsao G: Portal hypertension. Curr Opin Gastroenterol 2006,22:254-62.

6. Tan J, Surti B, Saab S. Pregnancy and cirrhosis. Liver Transpl 2008;14:1081-91.

7. Cheng YS. Pregnancy in liver cirrhosis and/or portal hypertension. Am J Obs Gynecol 1977, 128:812-22.

8. MacDorman MF, Hoyert DL, Martin JA, Munson ML, Hamilton BE. Fetal and perinatal mortality, 2003. Natl Vital Stat Rep 2007;55:1-18.

9. Boursier J, Vergniol J, Sawadogo A, et al The combination of a blood test and Fibroscan improves the non-invasive diagnosis of liver fibrosis. Liver Int 2009;29:1507. 